\title{
UNLOCKING THE IK INSTRUMENTAL CASE ${ }^{1}$
}

\author{
Terrill Schrock \\ SIL Uganda
}

\begin{abstract}
Ik, a Kuliak (Nilo-Saharan) language spoken by roughly 7000 people in northeastern Uganda, has up to now been described as having a case system with seven cases (König 2002, 2008). However, evidence from morphophonological variations on case suffixes requires that an eighth case be posited. Based on the semantic roles the eighth case marker encodes, it can be called the 'instrumental' case. The present paper provides a brief description of this so-named instrumental case in Ik. It does so by first giving an overview of the allomorphy of all eight case suffixes to provide some analytic context for distinguishing the instrumental from other case markers, particularly the ablative. Then it gives examples of the six semantic case roles that the instrumental case suffix encodes. By introducing an eighth case, the paper shows that a supposed instance of case syncretism (between the ablative and the instrumental) should no longer be thought to obtain in this East African language.
\end{abstract}

\section{Introduction}

Ik, a Kuliak (Nilo-Saharan) language spoken by roughly 7000 people in northeastern Uganda, is one of the hundred or so languages in Africa that have been described as having a case system (König 2002:284). The latest scholarly treatment of the Ik case system posits seven cases: nominative, accusative, dative, ablative, genitive, copulative, and oblique (König 2002:22). New morphological and semantic evidence, however, requires that an eighth case - the instrumentalbe posited.

Linguistic knowledge of Ik case has evolved over the decades as more of the language's phonology and morphology has come to light. In particular, morphophonological issues affecting case, like suffixation strategy, consonant deletion, vowel devoicing, vowel harmony, and vowel assimilation had obfuscated various proposed analyses. This created a situation where case homophony and thus case syncretism ${ }^{2}$ (between the ablative and the instrumental) were mistakenly thought to obtain in Ik. As it turns out, the mystery of this supposed case syncretism can be unlocked through close attention to slight morphophonological variations on nouns formerly thought to be inflected for the ablative case. And then once the two case suffixes can be teased apart, so can their distinct semantic roles.

This paper introduces the Ik instrumental case by providing a brief description of it. It begins with an overview of the allomorphy of all the case suffixes, followed by an account of the analytical emergence of the instrumental from the ablative. The last section briefly discusses the semantic roles now attributed to the instrumental case. The goal of the paper is to advance our understanding of Ik's intricate and unique morphological case-marking system.

\footnotetext{
${ }^{1}$ An earlier version of this paper was presented on 29 August, 2012, at the annual Conference on African Languages \& Linguistics, Leiden University, Holland. Thanks are due SIL colleagues Oliver Stegen and Helen Eaton whose prior comments were of considerable help in improving the paper before its presentation.

${ }^{2}$ I.e., "the realization by the same case of two or more different case roles" (Matthews 2007:50).
} 


\section{Overview of Ik case suffixes}

Ik 'has case' in the sense that it employs "an inflexional system of marking nouns or noun phrases for the type of relationship they bear to their heads (König 2008:5)." More specifically, Ik uses case markers (see Table 1 below) to encode core and non-core arguments in a clause. These markers are found only on the heads of noun phrases, and they are always the final morpheme on a nominal (or nominalized verbal) stem. Syntactically, the Ik case system is 'split-accusative': in unmarked clauses, subjects $(\mathrm{A} / \mathrm{S})$ take the nominative case, and objects $(\mathrm{O})$ take either the nominative (for $1^{\text {st }}$ and $2^{\text {nd }}$ person subjects) or the accusative (for $3^{\text {rd }}$ person subjects). Other marked clause types exhibit further case configurations. The unusual syntax of Ik case is not dealt with further in this paper. For more information about it, please refer to König 2002 for an indepth study or König 2008 for an overview.

2.1 Case morphemes. Morphologically, even though Ik has eight cases, it uses only seven overt case-marking suffixes. The remaining case-the oblique-is zero-marked (Ø). Ik case morphemes, presented here in Table 1, are subject to extensive allomorphic variations which are described below.

Table 1-Ik case morphemes

\begin{tabular}{l|l|l}
\hline Case & Case suffix & Suffixation strategy \\
\hline Nominative & $-\mathrm{a}$ & Absorbs stem-final vowel \\
Instrumental & $-\mathrm{s}$ & \\
\hline Ablative & $-\mathrm{s}$ & Attaches to stem-final vowel \\
Genitive & $-\varepsilon$ & \\
Accusative & $-\mathrm{ka}$ & \\
Dative & $-\mathrm{k} \varepsilon$ & \\
Copulative & $-\mathrm{k} \jmath$ & \\
Oblique & $-\varnothing$ &
\end{tabular}

As Table 1 shows, case morphemes in Ik can consist of a single vowel, null, or a single CV sequence. Case suffixes are toneless, and noun stems spread tone to them in systematic patterns. ${ }^{3}$

The third column in Table 1 above, labeled 'Suffixation strategy', captures two classes of Ik case suffixes divided on the basis of what effect they have on nominal stem-final vowels. All Ik nouns and nominal affixes have an underlying form that ends in a vowel, for example:

$\begin{array}{llll}\text { (1) yókí- } & \text { 'dog' } & \text { dàkú- } & \text { 'tree' } \\ \text { sìsí- } & \text { 'mead' } & \text { kàfờ- } & \text { 'thorn' } \\ \text { bóré- } & \text { 'corral' } & \text { déró- } & \text { 'rat' } \\ \text { nèkè- } & \text { 'hunger' } & \text { nòtó- } & \text { 'men' } \\ \text { kwàrá- } & \text { 'mountain' } & \text { kwár-íkà- 'mountains' }\end{array}$

\footnotetext{
${ }^{3}$ At the phonetic level, high pitch is marked as $\mathrm{V}$, low as $\grave{\mathrm{V}}$, and mid as $\mathrm{V}$, without a tone diacritic.
} 
When six of the eight case markers are suffixed to a stem, they attach to the stem-final vowel. By contrast, when the nominative and instrumental markers are suffixed to a stem, they absorb (or otherwise cause the disappearance of) the stem-final vowel. Understanding this simple difference between case suffixes is crucial to grasping the overall morphophonological behavior of the system.

2.2 Case allomorphy. Case-suffix allomorphy is relevant for this paper because it provides the necessary analytic context for distinguishing the instrumental case from other cases, particularly the ablative. The case suffixes shown in Table 1 are subject to several morphophonological variations, including k-deletion, devoicing, vowel harmony, and vowel assimilation. The first two, k-deletion and devoicing, operate from an important organizational principle in Ik: the clausal non-final/final distinction. According to this distinction, all morphemes in the language have two surface-level forms: non-final (NF) and final (FF). The non-final forms occur clause-medially, while the final forms occur clause-finally (i.e. before a pause). In the following sections, these four allomorphic variations are briefly described and exemplified with Ik data.

2.2.1 K-deletion. K-deletion refers to the intervocalic deletion of the segment $/ \mathrm{k} /$ in the non-final forms of the accusative, dative, and copulative cases. This produces non-final allomorphs for those three cases, as illustrated below in (2). The cause of k-deletion seems to be ease of articulation.

$\begin{array}{ll}\text { ACC } & \{-\mathrm{ka}\} \rightarrow\{-\mathrm{a}\} \ldots \\ \text { DAT } & \{-\mathrm{k} \varepsilon\} \rightarrow\{-\varepsilon\} \ldots \\ \text { COP } & \{-\mathrm{k}\lrcorner\} \rightarrow\{-\mathrm{\jmath}\} \ldots\end{array}$

Non-final k-deletion can be illustrated with a word like kàfơ- 'thorn', as in (3):

\begin{tabular}{|c|c|}
\hline ACC.NF & kàfò-ka \\
\hline DAT.NF & kàfù-ke \\
\hline COP.NF & kàfư-kə \\
\hline
\end{tabular}

2.2.2 Devoicing. In most discursive contexts, any vowel that occurs clause-finally and/or before a pause is devoiced. Phonetically, the devoicing may actually result in full deletion, depending on the nature of the consonant preceding the vowel. For case suffixes consisting of only a single vowel, the result is that the whole case morpheme is devoiced. For case suffixes consisting of a $\mathrm{CV}$ sequence, the result is that the $\mathrm{V}$ is devoiced, leaving a $\mathrm{C}^{\mathrm{v}^{4}}$ phonetic syllable. The clause-final allomorphs of case suffixes (except for the zero-marked OBL) are given in (4):

\footnotetext{
${ }^{4}$ Following a convention in Ik (Kuliak) studies, voiceless vowels are written with superscript symbols.
} 
(4)

$\begin{array}{ll}\text { NOM.FF } & \{-\mathrm{a}\} \rightarrow\{-\mathrm{a}\} \\ \text { INS.FF } & \{-\mathrm{-}\} \rightarrow\{-\mathrm{o}\} \\ \text { ABL.FF } & \{-\mathrm{-}\} \rightarrow\{-\mathrm{o}\} \\ \text { GEN.FF } & \{-\varepsilon\} \rightarrow\{-\varepsilon\} \\ \text { ACC.FF } & \{-\mathrm{ka}\} \rightarrow\left\{-\mathrm{k}^{\mathrm{a}}\right\} \\ \text { DAT.FF } & \{-\mathrm{k} \varepsilon\} \rightarrow\left\{-\mathrm{k}^{\varepsilon}\right\} \\ \text { COP.FF } & \{-\mathrm{k} \nu\} \rightarrow\left\{-\mathrm{k}^{o}\right\}\end{array}$

Vowel devoicing can also be illustrated with kàfờ- 'thorn', as in (5) below. Recall from Table 1 that the nominative and instrumental suffixes absorb the stem-final vowel, while the other cases do not:

\begin{tabular}{|c|c|c|}
\hline NOM.FF & kàf-a & $\rightarrow$ kàf-a \\
\hline INS.FF & kàf-っ & $\rightarrow$ kàf-` \\
\hline ABL.FF & àfù-o & $\rightarrow$ kàfù-` \\
\hline GEN.FF & fì- $\varepsilon$ & $\rightarrow$ kàfù_e \\
\hline ACC.FF & àfư-ka & $\rightarrow$ kàfù-k \\
\hline DAT.FF & $\varepsilon$ & $\rightarrow$ kàfù-k \\
\hline OP.FF & kàfư-ko & $f u ̛-k^{0}$ \\
\hline
\end{tabular}

2.2.3 Vowel harmony. Ik exhibits an [ATR]-based, [+ATR]-dominant vowel harmony system. For the purposes of case marking, this means that the underlyingly [-ATR] case suffixes are harmonized by [+ATR] roots. This yields [+ATR] allomorphs for those suffixes with vowels other than $/ \mathrm{a} /$, as in (6):

(6)

$$
\begin{array}{lll}
\mathrm{INS} & \{-\mathrm{o}\} & \rightarrow\{-\mathrm{o}\} /\{-\mathrm{o}\} \\
\mathrm{ABL} & \{-\mathrm{o}\} \rightarrow\{-\mathrm{o}\} /\{-\mathrm{o}\} \\
\mathrm{GEN} & \{-\mathrm{-}\} \rightarrow\{-\mathrm{e}\} /\{-\mathrm{e}\} \\
\mathrm{DAT} & \{-\mathrm{k} \varepsilon\} \rightarrow\{-\mathrm{e}\} /\left\{-\mathrm{k}^{\mathrm{e}}\right\} \\
\mathrm{COP} & \{-\mathrm{k} \rho\} \rightarrow\{-\mathrm{o}\} /\left\{-\mathrm{k}^{\mathrm{o}}\right\}
\end{array}
$$

This [+ATR]-dominant harmony in case suffixes can be seen in the [+ATR] word déró- 'rat', as in (7), where all case suffixes not possessing the vowel /a/ have taken on a [+ATR] value:

$$
\begin{aligned}
& \text { déró- 'rat' NF FF } \\
& \text { INS dér-o } \rightarrow \text { dér-ó dér-o } \\
& \mathrm{ABL} \text { déró-0 } \rightarrow \text { déró-ò déró- }{ }^{\circ} \\
& \text { GEN déró- } \varepsilon \rightarrow \text { déró-è déró-e } \\
& \text { DAT déró-ke } \rightarrow \text { déró-è déró-k }{ }^{\mathrm{e}} \\
& \mathrm{COP} \text { déró-ko } \rightarrow \text { déró-ò déró-k }{ }^{\circ}
\end{aligned}
$$

2.2.4 Vowel assimilation. Ik case suffixes both cause and undergo vowel assimilation in terms of the features for height, backness, and roundness. Case suffixes cause a range of both partial and total assimilation in stem-final vowels. One case suffix - the genitive $\{-\varepsilon\}$-also undergoes height assimilation when following high vowels. Both types of assimilation are described below. 
When any noun stem of either [ATR] value ends in /a/, the /a/ assimilates totally to a following case suffix in non-final environments only. This does not occur clause-finally (before a pause). This type of assimilation can be seen in words like kwàrá- 'mountain' and sédà- 'garden', as shown in (8):

$\begin{array}{lll}\text { GEN/DAT.NF } & \text { kwará- } \varepsilon & \rightarrow \text { kwaré- }-\varepsilon \\ \text { ABL/COP.NF } & \text { kwará-ó } \rightarrow \text { kwaró-ó } \\ \text { GEN/DAT.NF } & \text { sédà-è } & \rightarrow \text { sédè-è } \\ \text { ABL/COP.NF } & \text { sédà-ò } & \rightarrow \text { sédò-ò }\end{array}$

In certain vocalic combinations, the stem-final vowels (other than /a/) of [-ATR] stems like kàfó'thorn' and n’̀t'́- 'men', may optionally be totally assimilated by case suffixes, as (9) illustrates:

$\begin{array}{lll}\text { ABL/COP.NF } & \text { kàfù-ò } & \rightarrow \text { kàfò-ò } \\ \text { GEN/DAT.NF } & \text { jotó-ć } & \rightarrow \text { not } \varepsilon-\varepsilon\end{array}$

When a stem ending in the high vowels $/ \mathrm{I} /$ or $/ \mathrm{i} /$ takes the ablative or copulative suffixes, the stemfinal vowels are backed obligatorily to $/ \mho /$ and $/ \mathrm{u} /$, respectively, as in the following examples:

$$
\begin{aligned}
& \text { (10) dog- ABL/COP.NF yókí-ò } \rightarrow \text { yókú-ò } \\
& \text { dog- ABL.FF } \quad \text { jókí-o } \rightarrow \text { yókú- }^{\circ} \\
& \text { dog- COP.FF } \quad \text { yókí-k }{ }^{\circ} \rightarrow \text { jókú- } k^{\circ} \\
& \text { dogs- ABL.FF } \quad \text { jók-ítíní-o } \rightarrow \text { jók-ítínú- }{ }^{\circ} \\
& \text { horns- ABL.FF Éb-Itíní-จ } \rightarrow \text { ćb-Itínú-จ }
\end{aligned}
$$

Finally, one case suffix undergoes assimilation rather than causing it. That is, when the finalform of the genitive suffix $\{-\varepsilon\}$ is affixed to a stem whose final vowel is a high back vowel, the genitive-case vowel is raised. This raising is exemplified in (11) with a [-ATR] and a [+ATR] stem:

$$
\begin{array}{lll}
\text { thorn-GEN.FF } & \text { kàfù- } \varepsilon^{-} & \rightarrow \text { kàfù- }{ }^{\mathrm{I}} \\
\text { tree-GEN.FF } & \text { dakú- }^{\mathrm{e}} & \rightarrow \text { dakú- }^{\mathrm{i}}
\end{array}
$$

\section{The instrumental case}

Now that the rudiments of the case-marking suffixes have been laid out, the separation of the instrumental case from the ablative will make more sense. In particular, and most importantly, the two case suffixes differ with respect to how they affect stem-final vowels. As mentioned above, up through the most recent account of Ik case (König 2008), the existence of an instrumental case in Ik was not known. This section relates the emergence of the instrumental case from the ablative and goes on to describe the case roles handled by the instrumental as opposed to the ablative.

3.1 Instrumental case marker. The Ik instrumental case came to light through a comparison between similar but crucially different case-inflected noun forms. Insights into these different forms arose from a couple of culturally relevant questions, as presented below. In a relatively 
small, tight-knit society like that of the Ik people, knowing each other's whereabouts is an important part of daily life. Asking someone you meet on the trail where they have come from or where they are going is so routine it is practically a greeting. When someone has come as far away as Kaabong (40 km), the district capital, a secondary question one might ask is whether the person has come on foot, as opposed by bicycle, motorcycle, or vehicle. This common inquiry takes the following shape in Ik:

(12) atsídà nàà dèikj̀

àts-íd-à nàkà ${ }^{5}$ dè -ìk-っ

come-2SG-REAL PST1 foot-PL-INS.NF ${ }^{6}$

'Did you come on foot (i.e., by feet)?'

To which the reply, if the person has come on foot, usually is:

(13) ee atsíà nàà dè̀̀ ${ }^{\circ}$

ee àts-í-à nàkà dè-ik-o

yes come-1SG-REAL PST1 foot-PL-INS.FF

'Yes, I came on foot (i.e., by feet).'

The first inkling that something other than the ablative case was occurring in (12) and (13) came through a comparison with another question-answer pair involving the ablative:

(14) áts'á bì̀ dè̀̀̀̀̀

áts'-á bì -ka dè -ìkà-o

bite[3SG]-REAL you-ACC.NF foot-PL-ABL.NF

'Is it hurting your feet (lit: Is it biting you from the feet?)?'

(15) ee áts'á ńcì̀ dè̀kào

ee áts'-á ńcì-ka dè -ìkà-っ

yes bite[3SG]-REAL me-ACC.NF foot-PL-ABL.FF

'Yes, it's hurting my feet (lit: It's biting me from the feet.).'

In the interrogative (non-final, voiced) forms of the Ik word for 'feet' in (12) and (14), the only audible difference is in vowel length. That is, in (12), the word for 'feet' is pronounced with a short vowel [o], while in (14), it is pronounced with a long vowel [0:]. The affirmative forms in (13) and (15) even more clearly bring out the crucial difference-(13) with the devoiced case suffix absorbing the stem-final vowel and attaching to a consonant $\left[\mathrm{k}^{\mathrm{j}}\right]$, and (15) with the devoiced case suffix attaching directly to the stem-final vowel $\left[\mathrm{a}^{\mathrm{p}}\right]$. These slight but real variations challenge the notion that (12)-(15) all involve the same case marking suffix.

With the data in (12)-(15) as an impetus, other nouns were investigated in similar syntactic and semantic contexts. Gradually it became clear that both the established ablative case and the as yet unknown case had -o as their morphological marker. The only difference between them was shown to lie in the fact that the ablative suffix attaches directly to the stem-final vowel, while the

\footnotetext{
${ }^{5}$ Intervocalic k-deletion occurs in other morphemes besides case suffixes.

${ }^{6}$ Questions in Ik require non-final (and therefore fully voiced) forms at the end of the phrase or clause.
} 
instrumental first absorbs the stem-final vowel. These different suffixation strategies are illustrated in Table 2:

Table 2-Ablative vs. Instrumental case declensions

\begin{tabular}{|c|c|c|c|c|c|}
\hline & \multirow[b]{2}{*}{ Basic form } & \multicolumn{2}{|c|}{ Non-final (NF) } & \multicolumn{2}{|l|}{ Final (FF) } \\
\hline & & Ablative & Instrumental & Ablative & Instrumental \\
\hline mountain & kwará- & kwaró-ó & kwar-o & kwará-o & kwar- ${ }^{\circ}$ \\
\hline corral & Góré- & bóré-o & bór-o & 6óré-o & bór-o \\
\hline hunger & jèk & nèkj̀-j̀ & jèk-ò & nèk $\grave{\varepsilon}_{-}^{-}$ & nèk-o \\
\hline $\operatorname{dog}$ & yókí- & yókú-o & yók-o & yókú-o & nók-o \\
\hline honey beer & SISÍ- & SISƯ-ó & SIS-J & SISÚ-D & SIS- $^{\circ}$ \\
\hline rat & déró- & déró-o & dér-o & déró-o & dér-o \\
\hline men & notó- & notó-ว́ & not-o & notó-` & not- \\
\hline tree & dakú- & dakú-ó & dak-o & dakú-o & dak-o \\
\hline thorn & kàfư- & kàfò-ò & kàf-j̀ & kàfù-` & kàf-` \\
\hline mountains & kwár-íkà- & kwáríko-っ & kwárík-っ & kwáríkà-॰ & kwárík- \\
\hline corrals & Gór-ítíní- & bórítínú-o & Górítín-o & bórítínú-o & bórítín-o \\
\hline
\end{tabular}

In Table 2, for each basic or underlying form, four different case-inflected forms are given. The first two represent the non-final allomorphs and include fully voiced case suffixes. The last two represent final allomorphs of the case morphemes whose final vowels have been devoiced. Though with some nouns, like nèkè- 'hunger' and kàfó- 'thorn', the only audible difference between the ablative and instrumental is in vowel length, with other nouns, like kwàrá- 'mountain' and dàkú- 'tree', tone and other vowel features like lengthening help distinguish between the two cases.

3.2 Instrumental case roles. This newly observed evidence for the instrumental case from morphophonology is corroborated by syntax and semantics. Case-inflected nouns with their final vowel absorbed, like the ones in the fourth and sixth columns of Table 2 above, have been found to encode semantic roles like 'instrument', 'path', 'comitative', 'manner', and 'time'. An additional role, unique for $\mathrm{Ik}$, is the progressive or 'combative' aspect involving nominalized verbs. These six roles, along with eight others, were all treated under the ablative case in König 2002. König's fourteen ablative case roles are here divided between the ablative and the instrumental, as indicated in (16): 
(16)

$\begin{array}{ll}\text { ABLATIVE } & \text { INSTRUMENTAL } \\ \text { Source } & \text { Instrument/Means } \\ \text { Sender } & \text { Path (König's motion (by)) } \\ \text { Location } & \text { Comitative } \\ \text { Partitive } & \text { Manner } \\ \text { Cause } & \text { Time } \\ \text { Agent } & \text { Progressive ('Combative') } \\ \text { (Neg. possessor) } & \\ \text { Standard } & \end{array}$

Examples of each instrumental case role are provided in the natural language data below. To the right of each sentence is given in [square brackets] the ablative form of the relevant instrumental form in the example. This is to facilitate comparison between the two morphophonologically similar forms.

3.2.1 Instrument/Means. First, the instrumental case is used to encode non-core arguments that denote an instrument or means by which an action is realized (hence the label 'instrumental'):

(17) kəkese ákina makúlíko ńdà sìsìbès

$\begin{array}{lllll}\text { kj̀k- } \varepsilon S \varepsilon & \text { ák-in-a } & \text { makúl-íkà-o } & \text { ńdà } & \text { sìsì- } \varepsilon s \varnothing \\ \text { close-SPS } & \text { mouth-POSS.PL-NOM } & \text { grass.over-PL-INS } & \text { and } & \text { line.with.leaves-INF[OBL] } \\ \text { 'And its openings were closed with grass covers and lined with leaves.' }\end{array}$

(18) taa buka nóó bia ínó taná

[ABL=ínóo]

taa bùk-a nòkò bì-ka ínó-o taná-a

that marry[3SG]-REAL PST3 you.SG-ACC animal-INS how.many[3SG]-REAL

'So he married you with how many animals?'

3.2.2 Path. Second, the instrumental case is used to encode non-core arguments that denote a 'path', that is, a place by or through which a motion or action is realized. In a deeper semantic sense, 'path' is instrumental in that the subject of the clause accomplishes its action or motion by going by or through such a place. Examples (19) and (20) below provide two instances of the 'path' role:

(19) atsímáà sàbò dìdik ${ }^{\mathrm{e}}$

$[\mathrm{ABL}=$ sàbò-ò $]$

àts-ímá-ko sàbà-o dìdì-ke

come-1PL.EXCL-SEQ river-INS up-DAT

'And we came up by way of the river.'

(20) Jatííni awóó xaino gáí

yàt-í-íni awá-o xan-ini-o gáí

run-PLUR-SEQ home-ABL side-POSS.PL-INS both

'And they ran from the home by way of both sides.' 
3.2.3 Comitative. Thirdly, the instrumental case is used to encode non-core arguments that denote a thing or person with which an agent goes somewhere. Semantically, this role is 'instrumental' in that the agent takes an object somewhere by compulsion to thereby achieve some goal. This case role is most common with inanimate objects or animate objects that have little control over the event. If the object is a willing participant, for example in a situation of accompanying someone somewhere, then the connector ńdà 'with' is used instead of the instrumental:

(21) Kóyáa naa kúrúbáyo

Kó-í-á nàkà kúrúbádì-o
go-1SG-REAL PST1 things-INS
'I went with (my) things.'

$\left[\mathrm{ABL}=\text { kúrúbádù- }^{0}\right]^{7}$

'I went with (my) things.'

(22) atsuo ẹakwa kayoo ńk zeiiké jík

àts-ì-ko e्àkw-a kà-ì-ko ńcì-o zè-Íli-ke jík

come-3SG-SEQ man-NOM go-3SG-SEQ I-INS big-1SG-SIM ADV

'And the man came and went with me when I was already quite grown up.'

The use of the instrumental in (22) indicates that once a dowry was paid, the woman had little control over her going as she was being led away as the property of the man. If she had gone on her own accord, it would have been worded instead as ńda ńc ' with me'.

3.2.4 Manner. Fourthly, the instrumental case is used to encode non-core arguments that denote the manner or the way in which an action is accomplished. Such non-core arguments have an adverbial function in that they modify the semantics of the main verb, giving further information on how an action is realized:

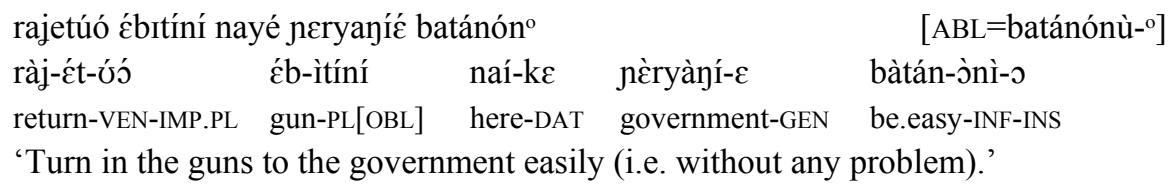

sca ni dúó kutanée hystodo yápèòn sc̀-a nì dî-ko kùt-àn-a-d $\varepsilon$ hyò-tódà-o yápèòn blood-NOM DEM.PL ONE.PL-COP say-IPS-REAL-DP cow-talk-INS yapeon 'This blood, it's is the one called yapeon in the Karimojong language.'

3.2.5 Time. Fifthly, the instrumental case is used to encode non-core arguments that denote the time during which an activity is undertaken. This case role is 'instrumental' in that a given period of time is used as chronological space through which an event or activity is can be achieved. The following two sentences give examples of the time semantic role:

\footnotetext{
${ }^{7}$ The root of 'things' in (21) is kúrúbádi-, but sometimes the /d/ is deleted.

${ }^{8}$ The root of ' $\mathrm{I} / \mathrm{me}$ ' in (22) is ńci- and is shorted to $\bar{n}^{\prime}$ before the nominative suffix $-a$ and the instrumental sufffix -0 . Then, with these two case suffixes, the /c/ is realized as a $/ \mathrm{k} /$. Furthermore, in this example, the instrumental suffix is devoiced, probably as a result of the narrator pausing briefly before the next word.
} 
(25) na noo kótó nekea gaaniyée kaíníko dí

nà nòkò koto nèkè-ka gààn-í-a-d $\varepsilon$ kàìn-íká-o dí

CONJ PST3 ADV hunger-ACC bad-PLUR[3SG]-REAL-DP year-PL-INS ANPH.PL

'So when hunger had gotten increasingly bad in those years...'

(26) hakwíána koto ado ákwédo kaIníć kòn

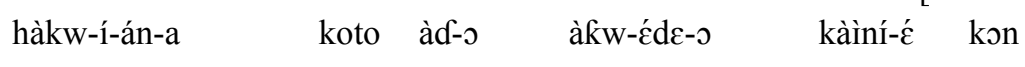

gather-PLUR-IPS-REAL ADV three-INS inside-PSSM.SG-INS year-GEN one

'So they [white-ants] are usually gathered three times in one year.'

3.2.6 Progressive aspect. Lastly, the instrumental case is used to mark arguments in a special syntactic construction encoding the progressive aspect. The construction is made up of the verb cغ̀m- 'fight' and a noun (or nominalized verb) in the instrumental case. So a clause like 'he is working' is rendered in Ik as 'he is fighting with work'. For this reason, it can also be called the 'combative' aspect:

(27) cema saa íbito waicíkáe

cèm-a sài-a íbìtà-o wà-ìcíká- $\varepsilon$

fight[3SG]-REAL others-NOM planting-INS greens-PL-GEN

'Others are planting greens (i.e. 'others are fighting with planting the greens').'

(28) cemésóô dìdì̀ wàt ${ }^{\circ}$

cèm- ́́s-ì-ko dìdì-a wàt

fight-IPFV-3SG-SEQ weather-NOM raining-INS

'And it was raining (i.e. 'the weather was fighting with raining'),'

\section{Concluding remarks}

In this paper it has been shown that due to evidence provided by morphophonological variation, an eighth case marker has to be separated out from the ablative in Ik. Once the separation has been done, the eighth case can be seen as marking case roles traditionally falling under the domain of the 'instrumental' case, broadly considered. In light of this, a situation of homophony and syncretism between the ablative and the instrumental cases should no longer be thought to obtain in Ik. The addition of the instrumental case warrants a new installment in the progression of Ik case studies, as Table 3 illustrates: 
Table 3 - Growing understanding of the Ik case morphemes (adapted from König 2002:45)

\begin{tabular}{l|l|l|l|l|l|l}
\hline & $\begin{array}{l}\text { Crazzolara } \\
(1967)\end{array}$ & $\begin{array}{l}\text { Tucker } \\
(1971-73)\end{array}$ & $\begin{array}{l}\text { Heine } \\
(1983)\end{array}$ & $\begin{array}{l}\text { Serzisko } \\
(1992)\end{array}$ & $\begin{array}{l}\text { König } \\
(2002,2008)\end{array}$ & $\begin{array}{l}\text { Schrock } \\
(2014)\end{array}$ \\
\hline NOM & --- & Isolation form & Abs./Nom. & Absolutive & Nominative & Nominative \\
ACC & $-\mathrm{k}$ & $3 p$ object & Accusative & Accusative & Accusative & Accusative \\
DAT & $-\mathrm{k}$ & Dative & Goal/Dative & Dative & $\begin{array}{l}\text { Dative } \\
\text { Genitive }\end{array}$ & Dative \\
GEN & Genitive & Genitive & Genitive & Genitive & Genive \\
ABL & - ao & Ablative & Source & Ablative & Ablative & Ablative \\
INS & --- & --- & --- & -- & Instrumental \\
COP & --- & Copulative & Copulative & Copulative & Copulative & Copulative \\
OBL & --- & --- & Basic form & Basis form & Oblique & Oblique
\end{tabular}

Unlocking the instrumental case takes us one step further toward deciphering the complicated case-marking system of this East African language. Nevertheless, if scientific progress and the history of Ik description have anything to teach us, this update on the Ik case system will not be the last. 


\section{Abbreviations}

$\begin{array}{llll}\text { ABL } & \text { ablative } & \text { IPS } & \text { impersonal passive } \\ \text { ACC } & \text { accusative } & \text { NF } & \text { non-final form } \\ \text { ADV } & \text { adverb } & \text { OBL } & \text { oblique } \\ \text { ANPH } & \text { anaphoric } & \text { PL } & \text { plural } \\ \text { CONJ } & \text { conjunction } & \text { PLUR } & \text { pluractional } \\ \text { COP } & \text { copulative } & \text { POSS } & \text { possessive } \\ \text { DAT } & \text { dative } & \text { PSSM } & \text { possessum } \\ \text { DEM } & \text { demonstrative } & \text { PST1 } & \text { recent past } \\ \text { DP } & \text { dummy pronoun } & \text { PST3 } & \text { remote past } \\ \text { EXCL } & \text { exclusive } & \text { REAL } & \text { realis } \\ \text { FF } & \text { final form } & \text { SEQ } & \text { sequential } \\ \text { GEN } & \text { genitive } & \text { SG } & \text { singular } \\ \text { IMP } & \text { imperative } & \text { SIM } & \text { simultaneous } \\ \text { INF } & \text { infinitive } & \text { SPS } & \text { sequential passive } \\ \text { INS } & \text { instrumental } & \text { VEN } & \text { venitive } \\ \text { IPFV } & \text { imperfective } & & \end{array}$

\section{References}

Crazzolara, F.J.P. 1967. General sketch: Grammar and vocabulary of the Ik (alias Teuzo). Typescript, Kang'ole, Uganda.

Heine, Bernd. 1983. The Ik language. Typescript. Cologne: Universität zu Köln.

König, Christa. 2002. Kasus im Ik. Rüdiger Köppe Verlag: Köln.

König, Christa. 2008. Case in Africa. Oxford University Press: Oxford.

Matthews, P.H. 2007. The Concise Oxford Dictionary of Linguistics. Oxford University Press: Oxford.

Serzisko, Fritz. 1992. Sprechhandlungen und Pausen: Diskursorientierte Sprachbeschreibung am Beispiel des Ik. (Linguistische Arbeiten, 282.) Tübingen: Niemeyer.

Tucker, A.N. 1971-73. Notes on Ik. African Studies, 30:341-54; 31:183-201; 32:33-48.

Terrill Schrock

P.O. Box 750

Entebbe, Uganda

terrill_schrock@sil.org
Submitted: 5 Sept 2012

Accepted: 19 Mar 2013

Revisions: 17 Mar 2014 